\title{
SMART GROWBOX DESIGN WITH TEMPERATURE AND HUMIDITY MONITORING SYSTEM VIA THE INTERNET
}

\author{
Wanda Vernandhes ${ }^{1}$, N.S Salahuddin ${ }^{2}$,A. Kowanda ${ }^{3}$ \\ Computer System Majoring, Gunadarma University ${ }^{1,2,3)}$ \\ Jl. Margonda Raya 100, Depok, Jawa Barat \\ E-Mail : wandavernandhes@student.gunadarma.ac.id ${ }^{l}$, \\ sultan,anacos@staff.gunadarma.ac.id ${ }^{2,3}$
}

\begin{abstract}
ABSTRAK
Pada tahun 2015, dengan perkiraan populasi 255 juta orang, Indonesia membutuhkan lahan seluas 13,38 juta hektar. Artinya, dalam beberapa tahun kedepan, Indonesia akan mengalami krisis lahan pertanian sehingga Indonesia dituntut untuk meningkatkan total areal budidaya. Hal ini disebabkan oleh meningkatnya perkembangan industri dan jasa, sehingga pertanian konvensional kurang kompetitif karena tingginya harga tanah. Salah satu pengembangan teknologi pertanian pertanian disebarkan teknologi budidaya pertanian yang layak dengan teknologi smart growbox memberikan alternatif bagi mereka yang tidak memiliki lahan untuk pertanian. Desain smartbox dengan sistem pemantauan suhu dan kelembaban melalui internet telah dirancang, dengan menggunakan sensor suhu dan kelembaban (DHT22) serta sensor kelembaban tanah (FC-28), maka kondisi tanaman dan lingkungannya akan mudah dipantau oleh melihat nilai output dari sebuah sensor. Hasil pengujian kecepatan rata - rata respon manual control via perangkat berbasis web adalah 5 detik. Kontrol kecepatan respon secara manual tergantung pada lalu lintas jaringan dan kondisi jaringan. Sistem siap untuk digunakan.
\end{abstract}

Kata kunci : Tanaman, Kotak Tumbuh, Teknologi, Internet, Mobile, Sensor, Suhu, Kelembaban.

\section{INTRODUCTION}

In 2015, with an estimated population of 255 million people, Indonesia requires 13.38 million hectares of land. Along with population growth, Indonesia need the increased area for farming so that food security can be stable. That is, Indonesia is required to increase the area cultivated area. In fact, agricultural land in Indonesia actually shrinking. According to the survey of the Ministry of Food Security Center (2010 2014), in 1999 - 2002, increased to 110,000 hectares of land conversion. In the period of 2002-2006 jumped to 145,000 hectares per year. However, in the 2007 - 2010 in Java, conversion rates an average of 200,000 hectares per year. He added that the land (irrigated rice technical, nontechnical, and dry land) in Java in 2007 was 4.1 million hectares, now only 3.5 million hectares. Wetland Indonesia is only 8.06 million hectares and moor / garden 12.28 million hectares. In a few years, Indonesia has encountered a crisis of agricultural land.
It was so, as found by the Bogor Institute of Agriculture (IPB), as many as 75 percent of the farmland in Indonesia decreased a significant fertility (Khudori).

With the data obtained from the Ministry of food security can be concluded that agriculture is the sector that has an important role in human life. Due to being a primary provider of food, clothing, and shelter in the walk of life, and a focus for community life in general. On one side, the development of science and technology world is so awesome it indeed has brought tremendous benefits for the progress of human civilization. This type of work in agriculture which previously required physical capacity is large enough, now it can be replaced by automatic machinery. Lack of awareness of the importance of information technology in agriculture may hinder the work or activities done, because by following the progress of technology and information, work can be done more effective and efficient. The use of 
technology in agriculture is often referred electronic agriculture (e-Agriculture).

One of the viable development of agricultural technologies is Smart Growbox that we will explain in this paper. This is caused by the increasing scarcity of land resources, especially since the development of industry and services, so that conventional agriculture is less competitive because of the high price of land. The concept of farming using technology Smart Growbox provides an alternative for those who don't have land for agriculture that stated in Food Security Department Survey data in order to carry out business activities that can be used as a source of food or adequate income. farming techniques applied Smart Growbox is very different from the corresponding conventional farming techniques. In this smart technology development, Smart Growbox has more advantages compared to conventional farming :

a. Including an automatic irrigation system and circulatory, and growlight system that can replace spectrum of sunlight, temperature and humidity can be controlled in accordance with the needs of the plant.

b. Mobile monitoring plant that can be easily viewed on the web.

c. Has better fruit quality than conventional agricultural technologies.

d. Rarely produced fruit decay in the system because growbox has closed glass box.

e. Labor costs can be minimized in terms of economy.

f. Maintenance is much better and easier.

This paper is intended to solve problems arising either in agriculture or a limited land to sustain the needs of the food sector individual or mass production.

\section{LITELATURE REVIEW}

2.1. Digital-Output Relative Humidity \& Temperature Sensor / Module (DHT

22)

Relative humidity is a measure of the amount of water vapor contained within the air which is usually expressed as percentage humidity. Humidity is a very important environmental element that must be controlled for healthy plants. DHT-22 also known as AM2302, is temperature and humidity sensor variants such as DHT-11, but it has advantages, which output on a sensor already in the form of digital signals with the conversions and calculations done by the integrated 8-bit MCU.

DHT22 sensor calibrated accurately with compensation temperatures in space adjustment with the calibrated coefficient values stored in memory integrated OTP, so that the sensor has a wider accuracy, precision and range measurements of temperature and humidity. This sensor is able to transmit the output signal passing through a long cable (up to 20 metres) making it suitable to be placed anywhere, with a note if you use the cable with a length of over $2 \mathrm{~m}$, add a buffer capacitor $0.33 \mu \mathrm{F}$ between pins \# 1 (VCC) and pin \# 4 (GND).

An optimal temperature range within which a particular plant species will be carrying out photosynthesis at its maximum rate (given that sufficient $\mathrm{CO} 2$, water and light are also present) outside this range, photosynthesis and other plant processes begin to slow down, to the point where they stop and growth ceases (Gene Giacomelli, Ph.D).

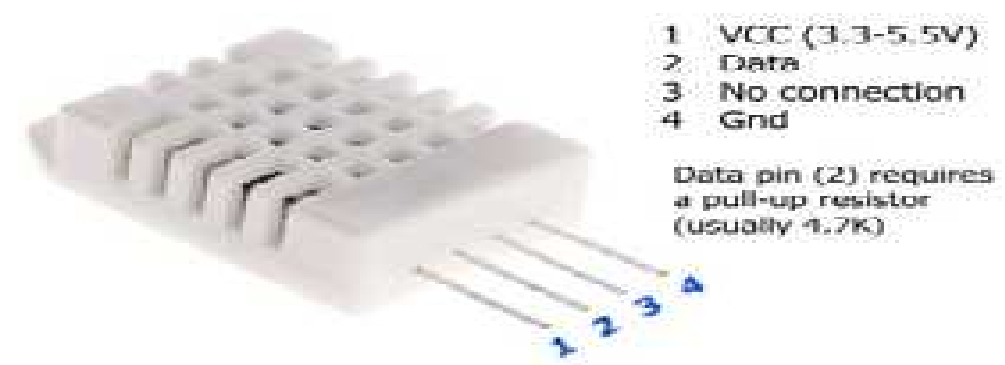

Figure 1. DHT22 Digital Temperature and Humidity Sensor. 
The temperature sensor used in the design of this tool is DHT22, as shown in figure.1. DHT22 calibrated output a digital signal. DHT22 sensor uses 3 pin input, namely VCC, Data, and Gnd as shown in figure 2 .

\subsection{Soil Moisture Sensor}

The lack of accuracy in the measurement of soil moisture is a serious problem. Clearly, there is needed for continuous measurements of surface soil moisture. Also, remote soil moisture sensing increases the efficiencies of irrigation systems by preventing over watering and leaching of fertilizers and other chemicals offsite. Soil Moisture sensor FC28 comes with a pair of tech probes that can be inserted in the soil. A small current flow through the probes and the level of resistance will be measured (GrowLED). The resistance increases if the soil is dryer. The output from the sensor is an analogue output that can be connected to one of the analogue to digital port (ADC) available on the microcontroller board.

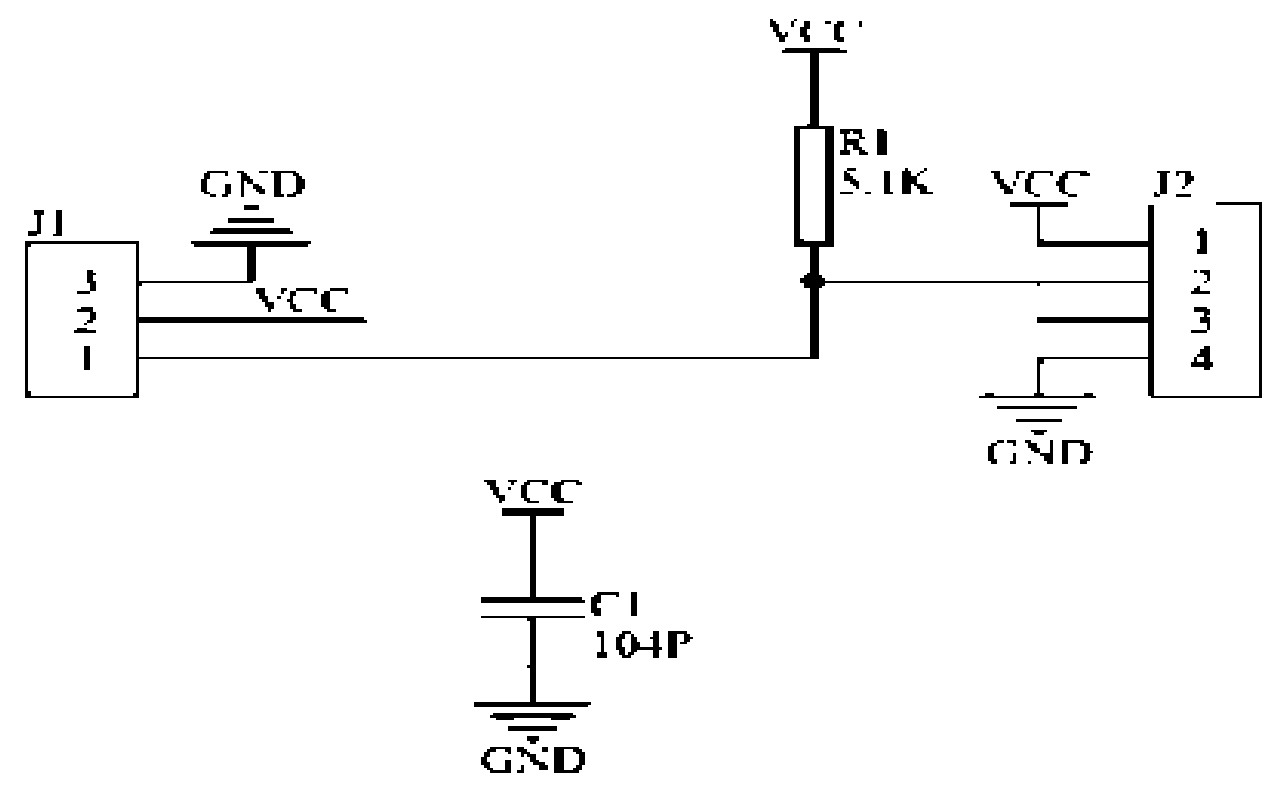

Figure 2. DHT22 Digital Temperature and Humidity Schematic.

\section{Technical Details :}

- Low cost.

- 3 to $5 \mathrm{~V}$ power and $\mathrm{I} / \mathrm{O}$.

- $2.5 \mathrm{~mA}$ max current use during conversion (while requesting data).

- Good for 0-100\% humidity readings with $2-5 \%$ accuracy.

- Good for -40 to $80^{\circ} \mathrm{C}$ temperature readings $\pm 0.5^{\circ} \mathrm{C}$ accuracy.

- No more than $0.5 \mathrm{~Hz}$ sampling rate (once every 2 seconds).

- Body size $27 \mathrm{~mm}$ x $59 \mathrm{~mm}$ x $13.5 \mathrm{~mm}$ (1.05" x 2.32 " x $0.53 ")$.

- 4 pins, 0.1" spacing.

- Weight (just the DHT22) : 2.4g.

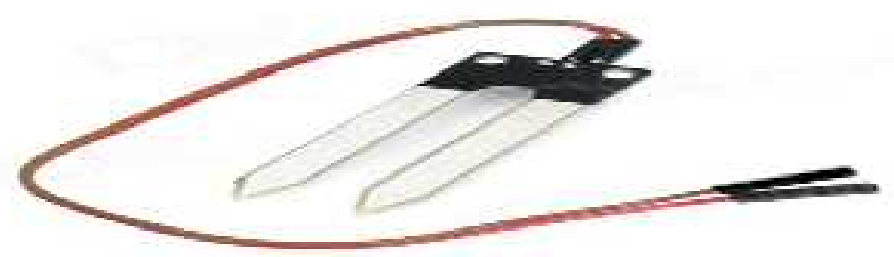

Figure. 3. FC-28 Soil Moisture Sensor. 
Table 1. Sensor Reading and Soil Condition

\begin{tabular}{cc}
\hline Sensor Reading & Soil Conditition \\
\hline $0-600$ & Wet Soil \\
$601-950$ & Moist Soil \\
$951-1023$ & Dry Soil \\
\hline
\end{tabular}

FC-28 soil moisture sensor module has been calibrated in order to verify accurate operation of the device, as shown in figure. 1 . A pot with potting soil was taken and the moisture levels are changed regularly. The pot was exposed to hot sun in order to get rid of the moisture. This allowed us to simulate a dry, arid soil environment. Similarly, the pot was watered to various levels, and the output from the sensor was recorded in table 1 .

\subsection{LED Grow Light}

Plants do not effectively use the entire spectrum of light. In fact, internal structures that absorb light inside plants such a chlorophyll and carotene absorb light in the range of two particular wavelengths.Most
LED Grow Lights deliver energy that plants need in the exact spectrums that are most effective to induce healthy and consistent plant growth (McRoberts, Michael, 2010). The Grow LED is available in Blue, Red and Blue / Red Combination to allow create the most effective growing environment, as shown in figure.4. It is recommended to control the amount of blue light delivered to the plant depending on the growth cycle of the target plant. In general the younger the plant, the more blue light that is required. Blue light can foster faster flowering, quicker fruit development (Hernandez, R, Sander W). Specifications and Dimensions :

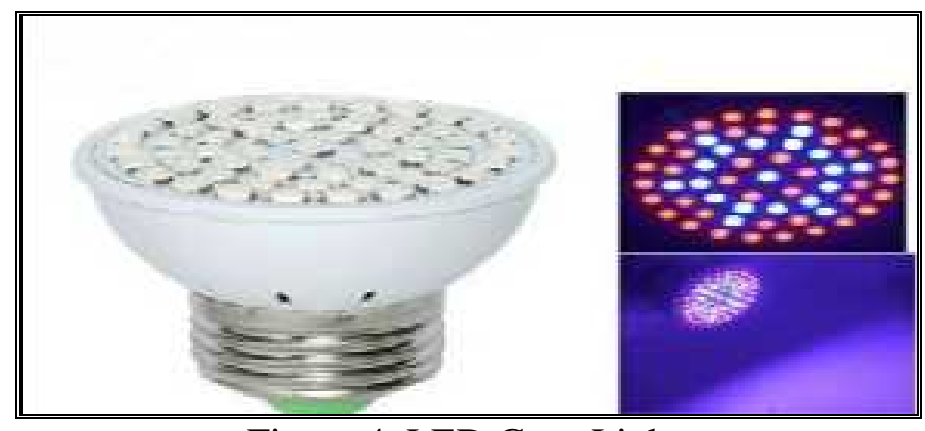

Figure 4. LED GrowLight.

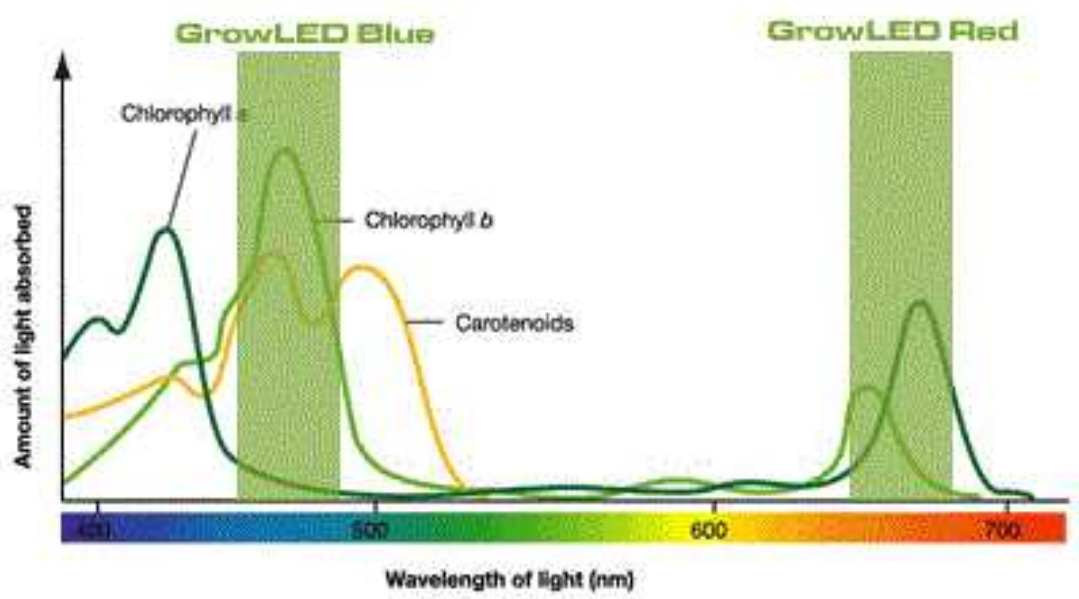

Figure 5. Charts The Influence of The Color Spectrum to Plants. 
- Power Consumption: 2 Watts.

- Luminous Flux: 300 Lumens.

- Light Engine: 168 LEDs (Red, Blue), Combination (130 Red, 38 Blue).

- Wavelengths: Red - 620-630 nm, Blue 460-470 nm.

- Input Voltage: 180 240V AC.

- Beam Angle - 120 Degrees.

- Lifespan: > 50,000 Hours (MTBF).

- Construction : ABS with Exposed LED Array.

- Physical Dimensions: Overall Length 5.08 in $(129.17 \mathrm{~mm})$, Diameter - 4.78 in (121.87 mm) Weight -4 Ounces.

Photosynthesis occurs mainly within the visible light spectrum (wavelength range 400 to 700 nanometers). Within this range, 445 nanometers (blue) and 650 nanometers (red) are needed most. Plants convert light into energy within their leaves. This is where the cholorophyll is stored, and is what plants use to convert light energy into chemical energy. Chlorophyll uses only very specific wavelengths of light to convert chemical energy. It doesn't use green light as we might initially think. Rather, it uses red light that is $600-680 \mathrm{~nm}$, and blue light that is $380-480$ $\mathrm{nm}$. Blue light is highest during the summer months and is responsible for growth of plants, while red lights is highest during the harvest months, and is responsible for the growth and development of flowers and fruit. Plant leaves absorb red and blue wavelengths of light, while reflecting green wavelengths. This is why leaves colour are green (Sander $\mathrm{W}$ and friends, 2012). As can be seen in figure 5, highest absorption is in the red and blue regions of the graph. The area between the two regions contains the green wavelengths, where there is minimal absorption. Thus when choosing lights to grow plants indoors or during night periods, it is important that they emit highly in the blue and red wavelengths in order to maximise plant growth.

\section{CONFIGURATION AND ARCHITECTURE}

The basic architecture of smart growbox is user access integrated with a graphical user interface via web monitoring and controlling. The system architecture is classified into three main points, namely client1 (users), server, and client2 (internal module) which can communicate via the server with different media, as shown in figure 6. The user will operate an experimental model of remotely through server. The server will forward any orders given to the experiment module. Output data from the microcontroller to be returned to the user via server.

In the scheme above can be seen that three elements are client 1 , servers and client2 can exchange data or information. Communication that occurs in the scheme is the type duplex communication. Users can make changes to parameters and data retrieval. The process is done by accessing the server address control and monitoring system on the web browser. In an internal module system consists of sensors, actuators, relays, arduino ethernet, and routers. On the server side of the system consists of a web server and an internet connection. System design experiments internet-based temperature and humidity requires good integration between control systems and monitoring, arduino ethernet, and web software. The picture below is the control system architecture that can explain the flow of how the system works.

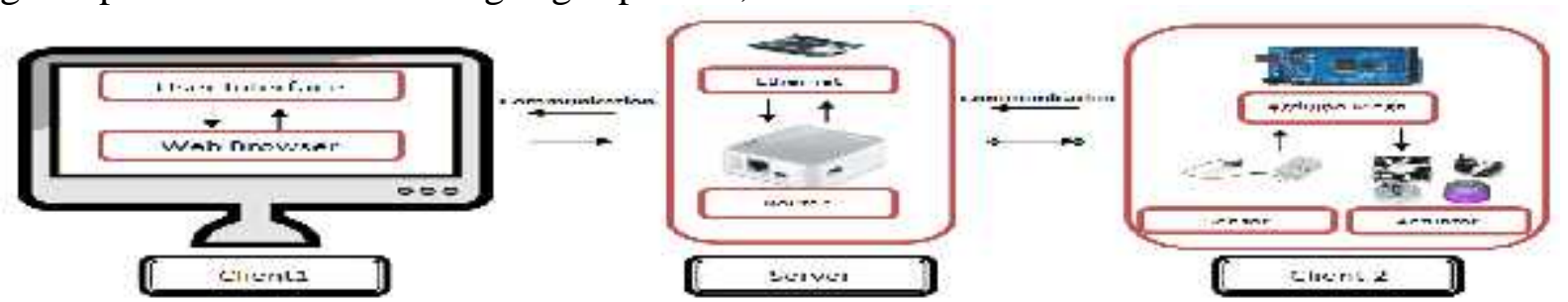

Figure 6. Communication Flow Devices and Components. 


\subsection{The Design of The Hardware}

The design of the system hardware consists of sensors, actuators, relays, arduino ethernet, and routers, as shown in figure 7. Hardware components are connected to one another to run the process control and monitoring as shown in figure 8 . The system monitors temperature and humidity is done using arduino, ethernet, FC-28 as a soil moisturise sensor and DHT11 sensor temperature correction incorporates in a single chip. Routers are used to connect the ethernet arduino with the server. Relay circuit serves as a control switch on / off from a wide variety of actuators as a form of response to the sensor output.
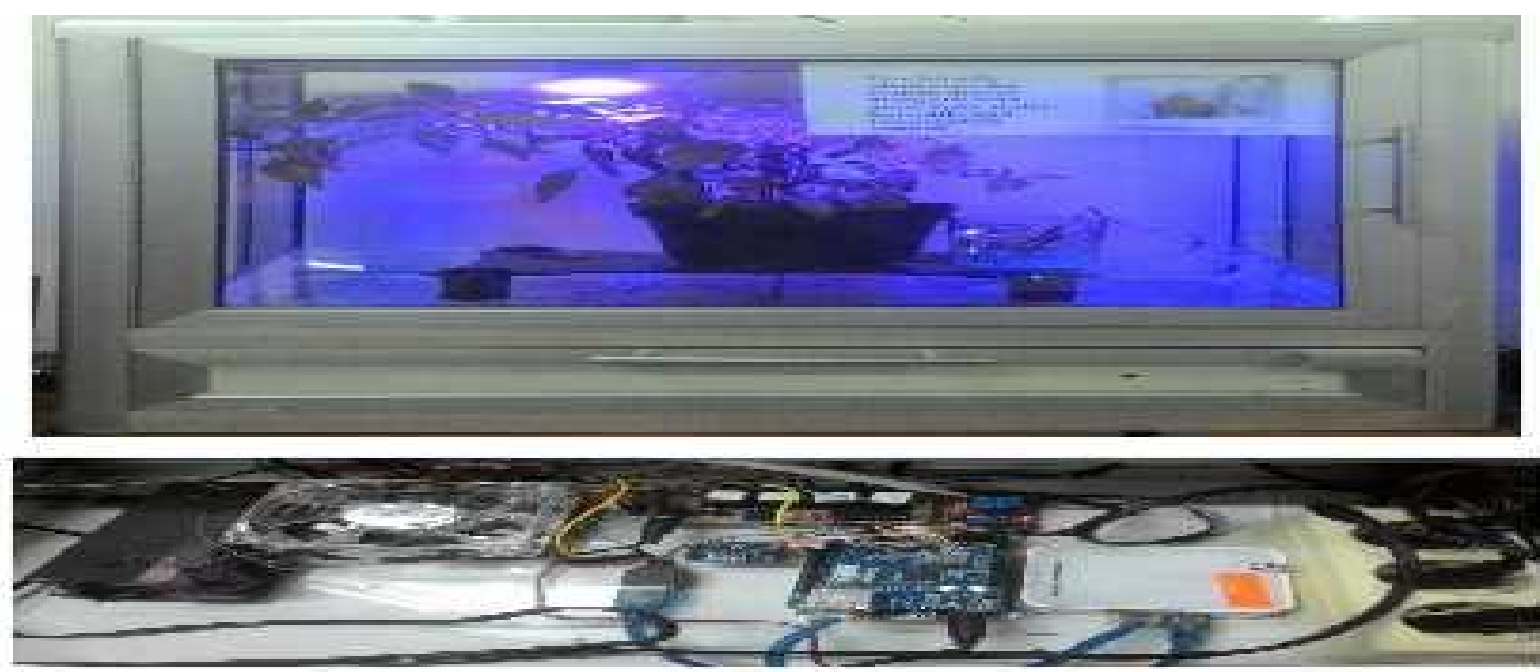

Figure. 7. Smart Growbox Platform Web-Based.

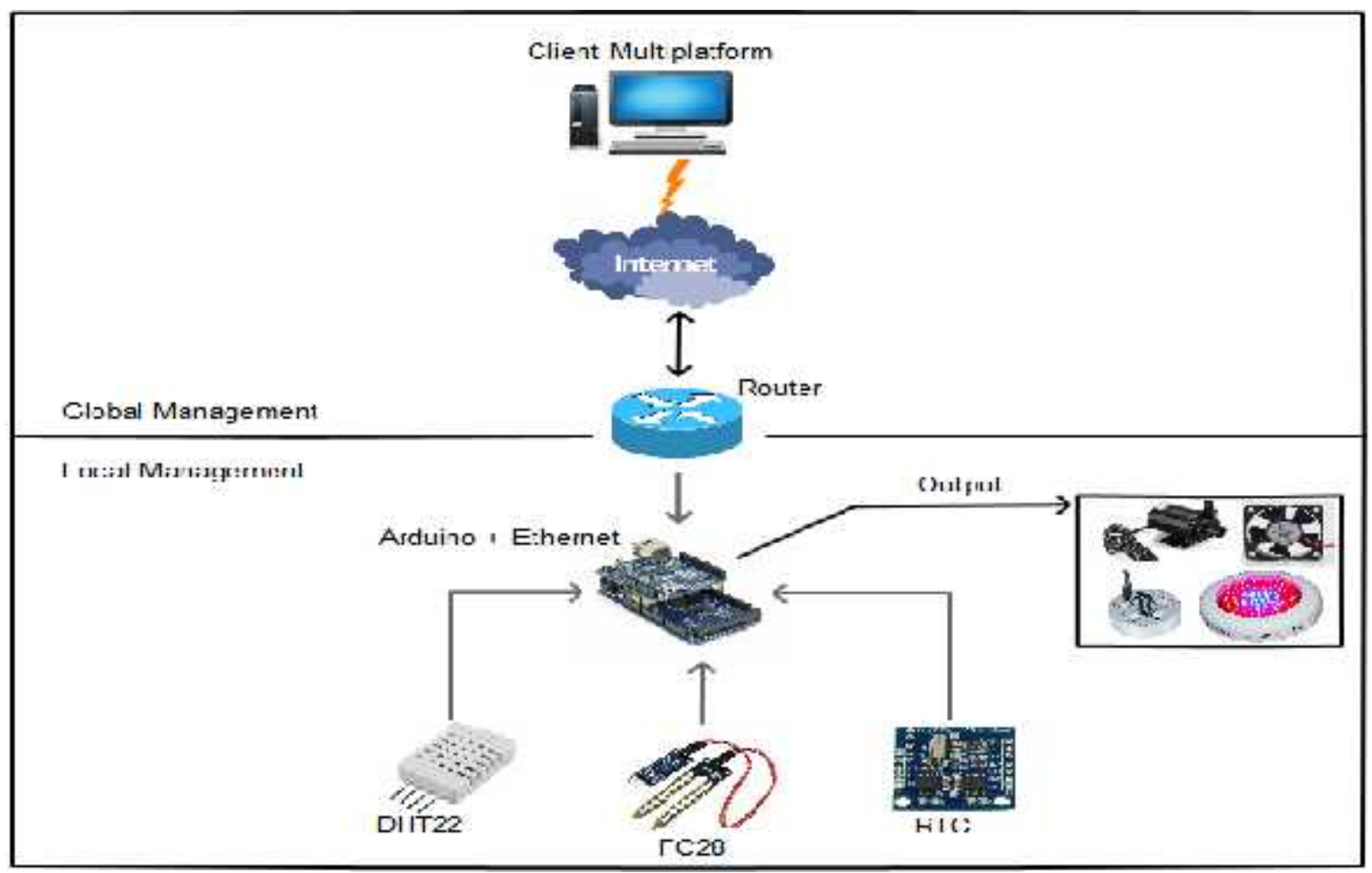

Figure. 8 .Architecture Control System and Monitoring Temperature and Humidity in Smart Growbox Based on Internet. 


\subsection{The Design of the Software}

The design of software system consists of Arduino program and server programs. Arduino program embedded in arduino ethernet to read the sensor input value of the soil, temperature and humidity DHT22, also read the time available on the Real Time Clock (RTC) module. These sensors emit a digital output. The value of the sensor readings are sent to arduino ethernet serially through an I2C (Inter-Integrated-Circuit) bus. Arduino Ethernet can transmit data of temperature and humidity as well as the status of the actuator to the server via the router using the GET method[9]. Additionally arduino ethernet can receive data from the client to run a manual or automatic mode. In manual mode arduino ethernet wait for user command to enable or disable various actuators. This program builds upon the flowchart in Figure 9 and uses the $\mathrm{C}$ programming language with Arduino compiler 1.0.5.

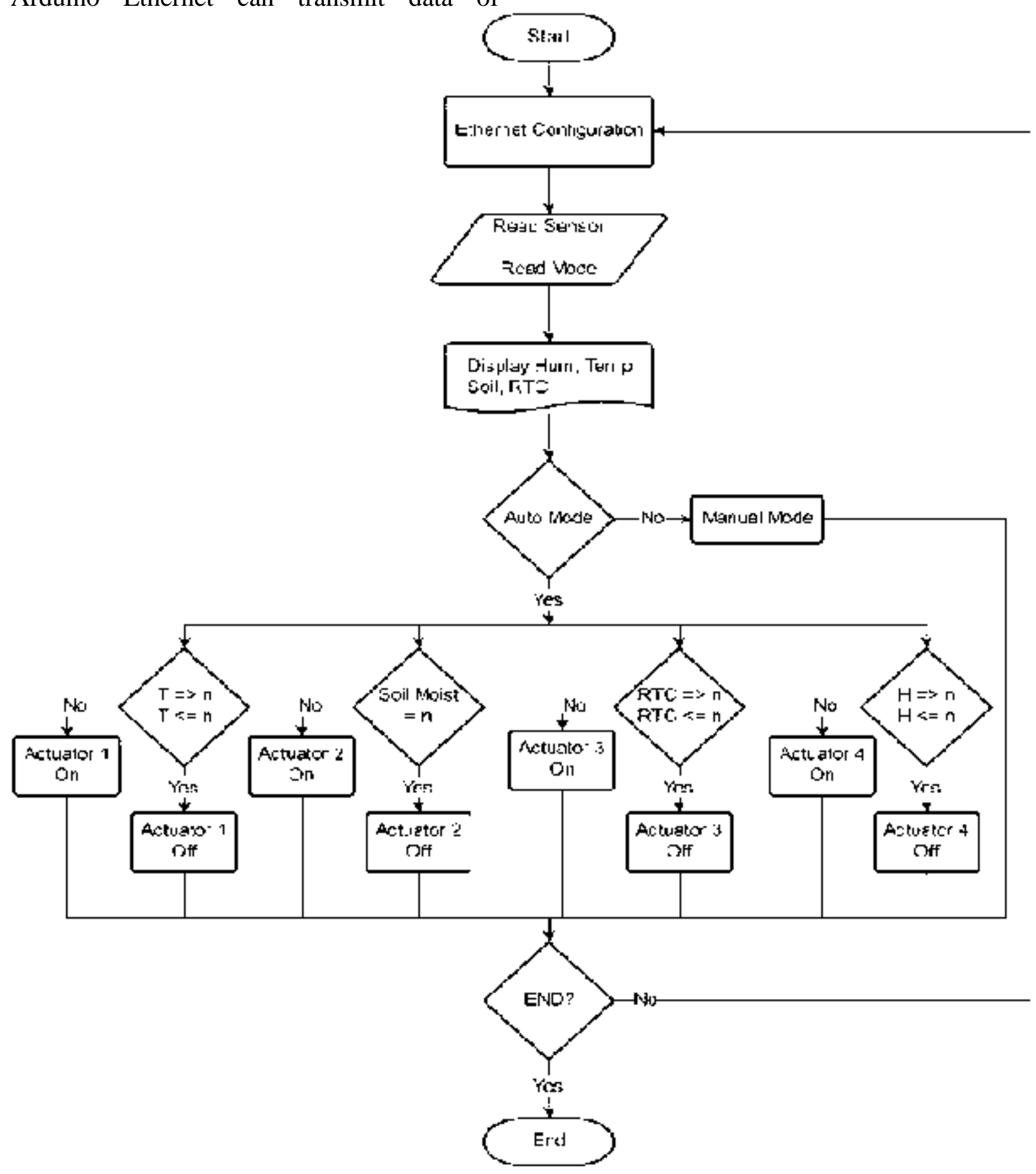

Figure 9. Flowchart Program Arduino Ethernet Shield. 
On flowchart can be seen that the server to display data on the web can through several stages. Early stage Arduino Ethernet Shield get data from reading sensor by Arduino Mega ADK. After getting temperature data, humidity air, humidity soil and also reading RTC that reads on Arduino Ethernet were sent to use of get data from server. To display web page of information datalog the writer use HTML programming language. When user go on a web pages, user can use auto mode and manuals mode designed in system and interface on web pages in order to facilitate user using smart growbox.

\section{RESULT AND TESTING}

Testing done on a system covering the measurement of air humidity, temperature and soil humidity of communication between servers with hardware and web interaction with users. There are two testing systems which is the system testing in a state of automatic and testing in a manual system.

Testing smart growbox based on internet in mode manual done with operating a system of module internal in remote through web browser. Testing use the operation of a computer Microsoft Windows with different web browser like the internet explorer, google chrome, mozilla firefox, netscape and operas. Display early appeared at the time when address smart growbox based the internet accessed through web browser google chrome.

\subsection{Testing Automatic Mode}

Testing automatic mode can be done by accessing web server that has ip address 192.168.0.1. When user has accessed web address so users can come into the user interface that is easy to catch information which was provided to web pages. Testing automatic mode done to see if a system can be monitoring and control on actuator and parameter that had been determined without of an instruction from user. The results of testing obtained that sensors able to perform the measurement of temperature, humidity air and humidity land well, arduino ethernet can monitor and send data, and relay can serve as a switch on various actuator. figure 10 is a client data obtained from trials in automatic mode.

According to the picture of figure $10 \mathrm{can}$ be seen that automatic programed with parameters preset by arduino code, the sensor reads the temperature of $27^{\circ} \mathrm{C}-30^{\circ} \mathrm{C}$ range or the humidity is between $65 \%-80 \%$ range or soil moisture is in the range of 601950 , the relay integrated in the sensor will be in off mode.

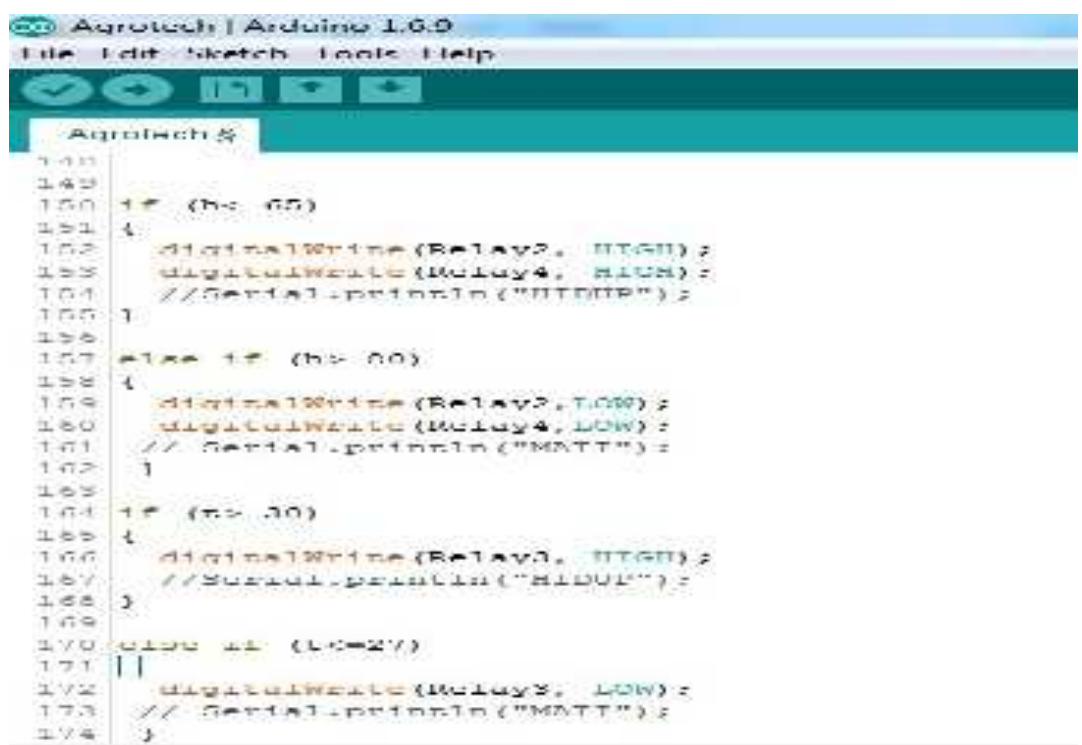

Figure 10. Arduino Program for Automatic Mode. 
On when the temperature exceeds $30^{\circ} \mathrm{C}$ so exhaust fan will mode on, and slowly temperature will decline, the same thing happens in humidity, if humidity below the $65 \%$ so mist maker will be turned on and if condition of the soil that is at the upper limit of more than 950, the water pump will be turned on. Cycle system will be easy to run when on automatic mode by determining parameter in embedded system. For logical reasoning with the parameters that have been planted on the system we can see on the pieces contained flowchart figure 9 conditions if you want to run automatic mode.

\subsection{Testing Manual Mode}

Testing automatic can be done by access web server having ip address 192.168.0.1. When user have accessed web address so user can come into the interface that is easy for user to take command of web pages. Testing manual mode done to see if a system can be controlled by user by operating actuator available on a platform Smart Growbox. The results of testing obtained that user can control and intervene to the state of temperature, humidity, and soil moisture in conformity with the wish user while running command manual mode. Command the user to on mode or off mode in actuator will be forwarded to arduino ethernet by reading data command of data type strings and send data, so that relay can serve as a switch on or off on various actuator. When the user intervene and give the command for mode on all actuator for three minutes then the temperature will drop in the temperature of $23^{\circ} \mathrm{C}$ due to an active exhaust fan and humidity will rise to the level of $89 \%$ as well as soil moisture which becomes wet with the reading value of 560. Based on the information in figure 11 . The test results showed that the client can control the device system remotely with an average speed of response for five seconds.

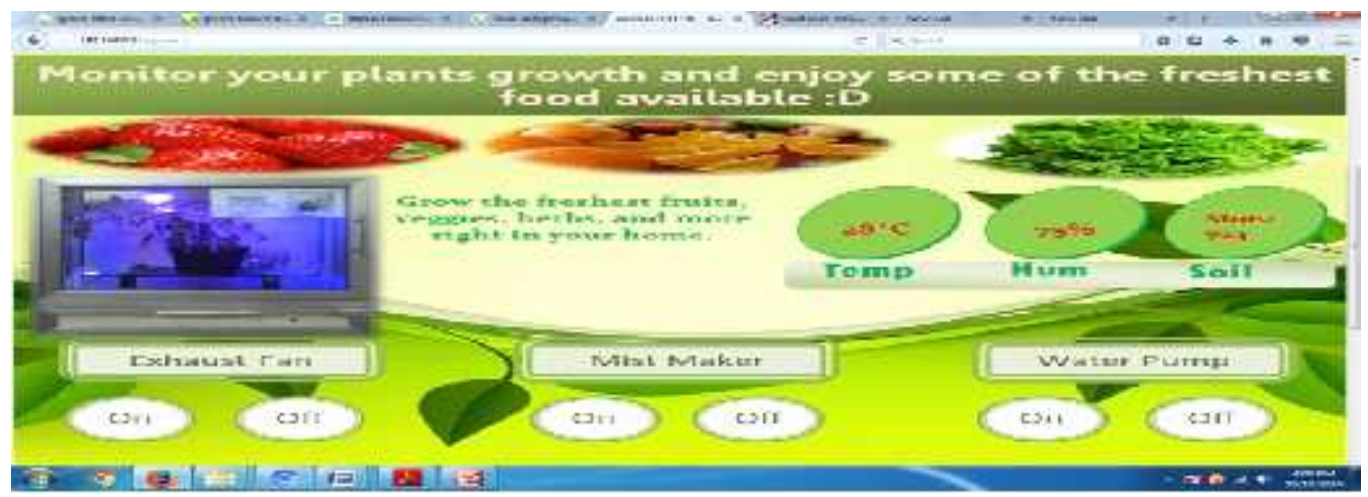

Figure 11. Data Display and Interface when The Automatic Mode is Executed.

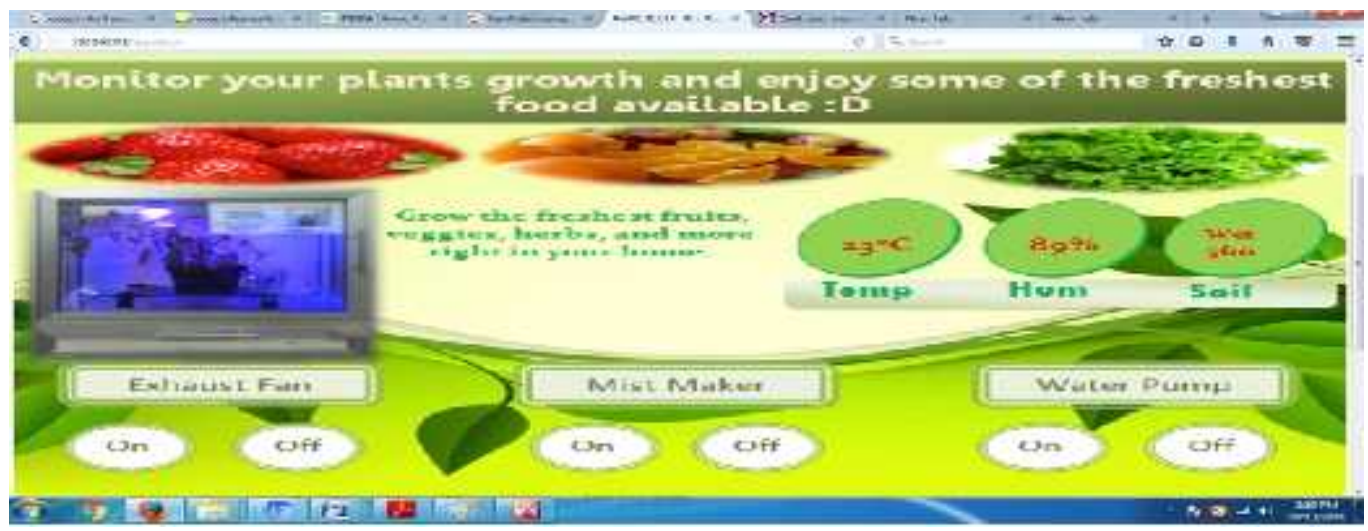

Fig 12. Data Display and Interface when The Manual Mode is Executed. 


\section{CONCLUSION}

Results of experiments performed in the laboratory obtained that this device can certainly tested and works as expected by observing and analyzing the input parameters to the program and the value of the output results from a reading of the sensor. Smart Growbox design with temperature and humidity monitoring system via internet and capable of monitoring temperature, humidity and soil moisture on Smart Growbox over the internet.

This system can be used in two modes, namely automatic mode and manually mode. Automatic mode can work with the maximum mode without the control of the user / client and the user can work well with a supporting web-based applications. Based on the result of the test, the client can controlled the actuator on device remotely with the average speed of response was 5 seconds. The response also depends on network traffic and network conditions. The system is ready for use.

\section{REFERENCES}

FC-28., 2016. Soil Moisture sensor spesification [Online]. www.nskelectronics.com/soilmoistu resensor.html.

Gene Giacomelli, Ph.D., Director of the Controlled Environment Agriculture Center at the University of Arizona, Interview.

GrowLED - GrowLight Green Planet Company http://www.greenplanetcompany.net Igrowled.html.

Hernandez, R., Plant Lighting Basics and Applications, University of Arizona.

Khudori., 2014. Badan Ketahanan Pangan "Survei Konversi Lahan Pertanian dan Perkebunan di Indonesia 20102014", POKJA Ahli Dewan Ketahanan Pangan Pusat. Jakarta.

McRoberts, Michael., 2010. "Beginning Arduino", Springer Science, New York.

Sander W. Hogewoning, Emilie Wientjes, Peter Douwstraa, Govert Trouwborst, Wim van Ieperen, Roberta Croce, and Jeremy Harbinson., 2012. Photosynthetic Quantum Yield Dynamics: From Photosystems to Leaves, American Society of Plant Biologists. 